\title{
The Social Space of Language
}




\section{SOUTH ASIA ACROSS THE DISCIPLINES}

South Asia across the Disciplines is a series devoted to publishing first books across a wide range of South Asian studies, including art, history, philology or textual studies, philosophy, religion, and interpretive social sciences. Contributors all share the goal of opening up new archives, especially in South Asian languages, and suggesting new methods and approaches, while demonstrating that South Asian scholarship can be at once deep in expertise and broad in appeal.

Edited by Dipesh Chakrabarty, Sheldon Pollock, and Sanjay Subrahmanyam

Funded by a grant from the Andew W. Mellon Fondation and jointly published by the University of California Press, the University of Chicago Press, and Columbia University Press.

1. Extreme Poverty: The South Asian Movement of Simultaneous Narration, by Yigal Bronner (Columbia University Press)

2. The Social Space of Language: Vernacular Culture in British Colonial Punjab, by Farina Mir (University of California Press)

3. Unifying Hinduism: The Philosophy of Vijnanabhiksu in Indian Intellectual History, by Andrew J. Nicholson (Columbia University Press) 


\title{
The Social Space of Language
}

\author{
Vernacular Culture in
}

British Colonial Punjab

Farina Mir

\section{ㅁ}

UNIVERSITY OF CALIFORNIA PRESS

Berkeley Los Angeles London 
University of California Press, one of the most distinguished university presses in the United States, enriches lives around the world by advancing scholarship in the humanities, social sciences, and natural sciences. Its activities are supported by the UC Press Foundation and by philanthropic contributions from individuals and institutions. For more information, visit www.ucpress.edu.

University of California Press

Berkeley and Los Angeles, California

University of California Press, Ltd.

London, England

(C) 2010 by The Regents of the University of California

An earlier version of Chapter 1 was published as "Imperial Policy,

Provincial Practices: Colonial Language Policy in Nineteenth-Century

India," Indian Economic and Social History Review 43, 4 (2006): 395-427.

Chapter 5 is reprinted in revised and expanded form from "Genre and

Devotion in Punjabi Popular Narratives: Rethinking Cultural and Religious

Syncretism," Comparative Studies in Society and History 48, 3 (July 2006):

727-58; reprinted with permission from Cambridge University Press.

\section{Library of Congress Cataloging-in-Publication Data}

Mir, Farina.

The social space of language : vernacular culture in British colonial Punjab / Farina Mir.

p. $\quad \mathrm{cm}$. - (South Asia across the disciplines ; 2)

Includes bibliographical references and index.

ISBN 978-0-520-26269-o (cloth : alk. paper)

1. Panjabi literature-19th century-History and criticism. 2. Panjabi literature-2oth century-History and criticism. 3. Literature and society-India-Punjab-History-19th century. 4. Literature and society-India-Punjab-History-2oth century. 5. Punjab (India)Intellectual life-19th century. 6. Punjab (India)-Intellectual life-2oth century. I. Title.

PK2650.5.M57 2010

891.4'209355-dc22

2009049413

Manufactured in the United States of America

$\begin{array}{lllllllll}19 & 18 & 17 & 16 & 15 & 14 & 13 & 12 & 11\end{array}$

$\begin{array}{llllllllll}10 & 9 & 8 & 7 & 6 & 5 & 4 & 3 & 2 & 1\end{array}$

This book is printed on Cascades Enviro 100, a 100\% post consumer waste, recycled, de-inked fiber. FSC recycled certified and processed chlorine free. It is acid free, Ecologo certified, and manufactured by BioGas energy. 